Pesq. Vet. Bras. 35(4):569-572, junho 2015 DOI: $10.1590 / \mathrm{S} 0100-736 X 2015000600014$

\title{
Relationship between weight, age and hatching success and the concentration of heavy metals in nestling blue macaw (Anodorhynchus hyacinthinus Latham, 1790) in the Pantanal, Mato Grosso do Sul ${ }^{1}$
}

\author{
Marina Drago Marchesi ${ }^{2 *}$, João L. Rossi ${ }^{3}$, Neiva M.R. Guedes ${ }^{4}$, Maria Tereza W.D. \\ Carneiro $^{5}$, Denise C. Endringer ${ }^{3}$ and Claudio Barberini Camargo Filho ${ }^{6}$
}

\begin{abstract}
Marchesi M.D., Rossi J.L., Guedes N.M.R., Carneiro M.T.W.D., Endringer D.C. \& Camargo Filho C.B. 2015. Relationship between weight, age and hatching success and the concentration of heavy metals in nestling blue macaw (Anodorhynchus hyacinthinus Latham, 1790) in the Pantanal, Mato Grosso do Sul. Pesquisa Veterinária Brasileira 35(6):569-572. Universidade Vila Velha, Av. Comissário José Dantas de Melo 21, Boa Vista, ES 20102-920, Brazil. E-mail: marina_marchesi@hotmail.com

The concentration of heavy metals ( $\mathrm{Cr}, \mathrm{Fe}, \mathrm{Al}, \mathrm{As}, \mathrm{Cd}, \mathrm{Cu}, \mathrm{Pb}, \mathrm{Mo}, \mathrm{Ni}, \mathrm{Se}$ and $\mathrm{Zn}$ ) was evaluated in the blood of nestling blue macaws (Anodorhynchus hyacinthinus) captured in the Pantanal, Mato Grosso do Sul $(n=26)$ in 2012; this was based on the hypothesis that these birds exhibit levels of these heavy metals in their organism and that these interfere in hatching success, weight and age of the chicks. Blood samples were digested with nitric acid and hydrochloric acid and the quantification of metals was performed by ICP-OES (Optical Emission Spectroscopy and Inductively Coupled Plasma). Blood samples of nestlings showed concentrations of $\mathrm{Cr}(0.10 \mu \mathrm{g} / \mathrm{g}) \mathrm{Fe}(3.06 \mu \mathrm{g} / \mathrm{g}) \mathrm{Al}(3.46 \mu \mathrm{g} / \mathrm{g}), \mathrm{Cd}(0.25 \mu \mathrm{g} / \mathrm{g})$ $\mathrm{Cu}(0.74 \mu \mathrm{g} / \mathrm{g})$, Mo $(0.33 \mu \mathrm{g} / \mathrm{g})$, Ni $(0.61 \mu \mathrm{g} / \mathrm{g})$, Se $(0.98 \mu \mathrm{g} / \mathrm{g})$, and $\mathrm{Zn}(2.08 \mu \mathrm{g} / \mathrm{g})$. The levels of heavy metals found were not associated with weight, age and hatching success of the chicks.
\end{abstract}

INDEX TERMS: Blue macaw, Anodorhynchus hyacinthinus, parrot, inorganic elements, bioindicators, minimally invasive methods, blood, environmental contaminants, pollution, reproduction, wild birds, Psittaciformes.

RESUMO.- [Relação entre peso, idade, sucesso de eclosãoeconcentraçãodemetaispesadosemfilhotesdearara-azul (Anodorhynchus hyacinthinus Latham, 1790) no Pantanal, Mato Grosso do Sul.] Avaliou-se a con-

\footnotetext{
${ }^{1}$ Received on January 12, 2015.

Accepted for publication on May 15, 2015.

${ }^{2}$ Aiuká Consultoria em Soluções Ambientais, Rua Bahia 362, Canto do Forte, Praia Grande, SP 11700-280, Brazil. *Corresponding author: marina_marchesi@hotmail.com

${ }^{3}$ Universidade Vila Velha, Av. Comissário José Dantas de Melo 21, Boa Vista, Espírito Santo, ES 20102-920, Brazil.

${ }^{4}$ Programa de Pós-Graduação em Meio Ambiente e Desenvolvimento Regional da Universidade Anhanguera Uniderp e Instituto Arara Azul, Rua Klaus Sthurk 178, Jardim Mansur, Campo Grande, Mato Grosso do Sul, MS 79051-660, Brazil.

${ }^{5}$ LabPetro - Universidade Federal do Espírito Santo (UFES), Av. Fernando Ferrari 514, Goiabeiras, Vitória, ES 29075-910, Brazil.

${ }^{6}$ Instituto Federal do Espírito Santo (IFES), Rua Teodoro P. Sauza 163, Alegre, ES 29500-000, Brazil.
}

centração de metais pesados (selênio, zinco, ferro, cobre, molibdênio, níquel, cromo, arsênio, cádmio, chumbo e alumínio) no sangue de filhotes de arara-azul (Anodorhynchus hyacinthinus) capturados no Pantanal $(\mathrm{n}=26)$ no ano de 2012, partindo da hipótese de que estas aves apresentem níveis desses metais pesados no organismo e que os mesmos tenham relação com o sucesso de eclosão, peso e idade dos filhotes. As amostras de sangue foram digeridas em ácido nítrico e ácido clorídrico e a quantificação dos metais foi realizada por ICP-OES (Espectroscopia e Emissão Óptica por Plasma Indutivamente Acoplado). As amostras de sangue de filhotes de A.hyacinthinus apresentaram concentrações de $\mathrm{Cr}(0,10 \mu \mathrm{g} / \mathrm{g})$, Fe $(3,06 \mu \mathrm{g} / \mathrm{g}), \mathrm{Al}(3,46 \mu \mathrm{g} / \mathrm{g}), \mathrm{Cd}$ $(0,25 \mu \mathrm{g} / \mathrm{g}), \mathrm{Cu}(0,74 \mu \mathrm{g} / \mathrm{g})$, Mo $(0,33 \mu \mathrm{g} / \mathrm{g}), \mathrm{Ni}(0,61 \mu \mathrm{g} / \mathrm{g})$, Se $(0,98 \mu \mathrm{g} / \mathrm{g})$ e $\mathrm{Zn}(2,08 \mu \mathrm{g} / \mathrm{g})$. Os níveis de metais pesados encontrados não apresentaram relação com o peso, idade ou sucesso de eclosão. 
TERMOS DE INDEXAÇÃO: Arara-azul, Anodorhynchus hyacinthinus, Psitacídeos, elementos inorgânicos, bioindicadores, métodos minimamente invasivos, sangue, contaminantes ambientais, poluição, reprodução, aves silvestres, psitaciformes.

\section{INTRODUCTION}

Animals and plants that inhabit polluted areas end up contaminating themselves by absorbing inorganic elements (Pereira \& Ebecken 2009).

Birds are considered bioindicators (Bost \& Lemaho 1993) particularly because they are sensitive to environmental changes and more prone to intoxications than other animals as they quickly disperse the toxic agent through their body by their respiratory system, metabolic rate and low amount of body fat (Cubas \& Godoy 2012).

Using nestling birds as indicators is beneficial because, according to their life spam, it is possible to standardize samplings (Furness 1993) and it deeply reflects the contamination of the studied habitat (Burger 1993, Furness 1993, Janssens et al. 2002).

Minimally invasive methods utilizing blood, feces, feather and egg may be used to quantify levels of heavy metals in the organism (Furness 1993, Dmowski 1999, Jaspers et al. 2004). The finding of levels of heavy metals in the blood indicates that the animal has been exposed to recent environmental contamination (Garcia-Fernandez et al. 1996).

One of the ecosystem that houses a large number of bird species is the Pantanal (Nunes et al. 2005) and even the endangered ones, such as the hyacinth macaw (Anodorhynchus hyacinthinus), are seen with relative frequency, having its largest population inhabiting the Pantanal (Guedes 2009).

The present study was performed under the hypothesis that the presence of heavy metals in the organism of Anodorhynchus hyacinthinus may influence the weight and age of nestlings, and the success of hatching. The objective was to determine the content of chromium $(\mathrm{Cr})$, iron $(\mathrm{Fe})$, aluminum (Al), arsenic (As), cadmium (Cd), copper $(\mathrm{Cu})$, lead $(\mathrm{Pb})$, molybdenum (Mo), nickel (Ni), selenium (Se) and zinc (Zn) in nestling $A$.hyacinthinus through blood analysis.

\section{MATERIALS AND METHODS}

The study was developed with 26 wild nestlings of Anodorhynchus hyacinthinus in the Pantanal, Mato Grosso do Sul, in December 2012. The materials consisted of whole blood samples, stored in micro tubes without anticoagulant. The study was approved by the Ethics in Research on Humans and animals ULBRA (CEP-ULBRA2006-016A).

Place of study. The study was performed in the base of the Hyacinth Macaw Project, located in the Caiman farm - REC $\left(19^{\circ} 51^{\prime}-19^{\circ} 58^{\prime} \mathrm{S}\right.$ and $\left.56^{\circ} 17^{\prime}-56^{\circ} 24^{\prime} \mathrm{W}\right)$, in the sub-region of Miranda, Pantanal, Mato Grosso do Sul. The area was composed of a semideciduous forest, flooded fields; islands of residual forest, riparian forest and fields formed by open areas. The average annual temperature was $25^{\circ} \mathrm{C}$, with rains during the summer and a dry winter.

Capture of nestlings. The nestlings were captured in their natural nests in the manduvi tree (Sterculia apetala), which is the tree most often used by the macaws to build their nests and artificial nests. To capture the nestlings, proper tree climbing equipment was used to reach the nests and the animals were placed within plastic buckets to be transferred from the nests to the ground.

Material collection. With the bird physically restrained, $1 \mathrm{ml}$ of blood was collected in the ulnar vein with the aid of a hypodermic needle $25 \times 73 \mathrm{~mL}$ and syringe. For the study, it was used approximately $1 \mathrm{~g}$ o blood stored in a microtube without anticoagulant and frozen at $-18^{\circ} \mathrm{C}$.

Analysis of the material. Blood samples were digested in a volume of $2 \mathrm{ml}$ of nitric acid $\left(\mathrm{HNO}_{3}\right)$ followed by $10 \mathrm{ml}$ of pure hydrochloric acid ( $\mathrm{HCl})$ to $5 \mathrm{~mol} / \mathrm{L}$, to lessen the influence of organic matter in the quantification of the metals.

Digestion was catalyzed in a digestor (Marconi A.M. 851 Mod) at $280^{\circ} \mathrm{C}$ for an hour (Garcia-Fernandez 1994, adapted) until solution became translucent. After digestion, the samples were transferred to a volumetric $25 \mathrm{~mL}$ flask and its volume was adjusted with ultrapure water type 1 (deionized and purified with Milli-Q system) and then stored in glass bottles and refrigerated at $4^{\circ} \mathrm{C}$ until analysis.

The multi-element standard solution for $\mathrm{Cr}, \mathrm{Fe}, \mathrm{Al}, \mathrm{As}, \mathrm{Cd}$, $\mathrm{Cu}, \mathrm{Pb}, \mathrm{Mo}, \mathrm{Ni}, \mathrm{Se}$ and $\mathrm{Zn}$ were prepared in concentrations between 0.0 and $2.0 \mathrm{mg} / \mathrm{mL}$. Quantification was performed on ICP-OES (optical emission spectroscopy, and inductively coupled plasma) and the limits of detection for each element were $\mathrm{Cr}=$ $0.1278 \mathrm{~g} / \mathrm{mL}, \mathrm{Fe}=0.7040 \mathrm{~g} / \mathrm{ml}, \mathrm{Al}=0.0631 \mathrm{mg} / \mathrm{mL}$, As $=0.0069 \mathrm{~g} /$ $\mathrm{mL} ; \mathrm{Cd}=0.6372 \mathrm{~g} / \mathrm{mL} ; \mathrm{Cu}=0.2151 \mathrm{~g} / \mathrm{mL} ; \mathrm{Pb}=0.0162 \mathrm{~g} / \mathrm{mL}$ Mo $=0.0879 \mathrm{~g} / \mathrm{mL} ; \mathrm{Ni}=0.0889 \mathrm{mg} / \mathrm{mL}, \mathrm{Se}=0.0585 \mathrm{~g} / \mathrm{mL}$ and $\mathrm{Zn}=$ $0.2310 \mathrm{~g} / \mathrm{mL}$.

The calibration curve for each metal was obtained by using triplicates and submitted to a regression of $95 \%$ confidence level.

The analysis of the influence of metals on the eggs' hatching success was done through the multiple logistic regression model to discriminate between the dependent variables "nest with all hatched eggs" (0) and "nest with unhatched egg" (1) and the independent variable "concentrations of metals" $\mathrm{Cr}, \mathrm{Fe}, \mathrm{Al}, \mathrm{As}, \mathrm{Cd}, \mathrm{Cu}$, $\mathrm{Pb}, \mathrm{Mo}, \mathrm{Ni}$, Se and $\mathrm{Zn}$ (Table 1). The relationship between size and weight of the nestling was tested by linear regression. To verify that the concentration of metals varies with the age and weight of nestling, the multiple linear regression (backwise stepwise) was applied. All results were considered statistically significant when $\mathrm{p}<0.05$.

\section{RESULTS}

Among the 11 analyzed metals, blood samples of nestling Anodorhynchus hyacinthinus presented concentrations of $\mathrm{Cr}, \mathrm{Fe}, \mathrm{Al}, \mathrm{Cd}, \mathrm{Cu}, \mathrm{Mo}$, Ni, Se and $\mathrm{Zn}$.

Levels of $\mathrm{As}$ and $\mathrm{Pb}$ were disregarded because they were below the detection limit.

All results for the median concentration of the heavy metals are shown in Table 2.

The levels of metals present in the blood should not be used to predict hatching (Table 3), because it did not influence it ( $p>0.05$ ) (Table 4).

The weight of nestlings used in this study did not show significant statistical correlation with the age of the nestlings ( $\mathrm{F}=1.91, \mathrm{p}=0.179)$.

The concentration of the tested metals did not vary according to age $(p>0.05)$ or weight $(p>0.05)$ of A. hyacinthinus nestlings. 
Table 1. List of nestling with respective values for weight (g) and age (days), hatching success, where the number one was used to determine "nest with unhatched egg" and the number zero to determine "nest with all hatched eggs" and the levels of metal concentration in the blood of Anodorhynchus hyacinthinus

\begin{tabular}{|c|c|c|c|c|c|c|c|c|c|c|c|c|}
\hline \multirow[t]{2}{*}{ Nestling } & \multirow[t]{2}{*}{ Weight (g) } & \multirow[t]{2}{*}{ Age (days) } & \multirow[t]{2}{*}{ Hatching } & \multicolumn{9}{|c|}{ Metals $(\mu \mathrm{g})$} \\
\hline & & & & $\mathrm{Cr}$ & $\mathrm{Fe}$ & $\mathrm{Al}$ & $\mathrm{Cd}$ & $\mathrm{Cu}$ & Mo & $\mathrm{Ni}$ & $\mathrm{Se}$ & $\mathrm{Zn}$ \\
\hline 746 & 1048 & 50 & 0 & 0.003 & 0.014 & 0 & 0.01 & 0.026 & 0.012 & 0.026 & 0.046 & 0.151 \\
\hline 747 & 1406 & 80 & 0 & 0.003 & 0 & 0.65 & 0.01 & 0.033 & 0.013 & 0.029 & 0.048 & 0.129 \\
\hline 748 & 1296 & 80 & 0 & 0.003 & 0 & 2,776 & 0.011 & 0.023 & 0.012 & 0.029 & 0.06 & 0.148 \\
\hline 749 & 1049 & 55 & 0 & 0.003 & 0.151 & 0.549 & 0.011 & 0.033 & 0.013 & 0.028 & 0.041 & 0.121 \\
\hline 759 & 1183 & 85 & 0 & 0.003 & 0.055 & 0.604 & 0.011 & 0.041 & 0.011 & 0.028 & 0.055 & 0.258 \\
\hline 760 & 1185 & 85 & 0 & 0.003 & 0.03 & 0.743 & 0.012 & 0.027 & 0.011 & 0.024 & 0.039 & 0.268 \\
\hline 761 & 1189 & 55 & 0 & 0.003 & 0.039 & 0.014 & 0.01 & 0.034 & 0.013 & 0.024 & 0.033 & 0.089 \\
\hline 762 & 1187 & 70 & 0 & 0.004 & 0.307 & 0.034 & 0.01 & 0.031 & 0.012 & 0.024 & 0.033 & 0.084 \\
\hline 763 & 1419 & 60 & 1 & 0.004 & 0.007 & 0.026 & 0.009 & 0.041 & 0.013 & 0.025 & 0.03 & 0.081 \\
\hline 764 & 1307 & 60 & 1 & 0.004 & 0.29 & 0.171 & 0.01 & 0.028 & 0.013 & 0.024 & 0.033 & 0.085 \\
\hline 765 & 1411 & 100 & 0 & 0.085 & 0.054 & 0.116 & 0.019 & 0.024 & 0.034 & 0.022 & 0.041 & 0.078 \\
\hline 766 & 1286 & 80 & 1 & 0.005 & 0.863 & 0.058 & 0.009 & 0.035 & 0.015 & 0.024 & 0.036 & 0.093 \\
\hline 767 & 1500 & 80 & 0 & 0.004 & 0.402 & 0.06 & 0.01 & 0.031 & 0.014 & 0.023 & 0.038 & 0.071 \\
\hline 768 & 1191 & 60 & 0 & 0.004 & 0.584 & 0.059 & 0.009 & 0.031 & 0.014 & 0.023 & 0.037 & 0.055 \\
\hline 769 & 1376 & 80 & 1 & 0.004 & 0.64 & 0.641 & 0.009 & 0.03 & 0.014 & 0.022 & 0.038 & 0.081 \\
\hline 770 & 1303 & 60 & 0 & 0.003 & 0.873 & 0.123 & 0.008 & 0.029 & 0.015 & 0.023 & 0.038 & 0.126 \\
\hline 771 & 1395 & 80 & 0 & 0.003 & 0.022 & 0.12 & 0.009 & 0.029 & 0.014 & 0.025 & 0.042 & 0.076 \\
\hline 772 & 1401 & 80 & 0 & 0.003 & 0 & 1,042 & 0.009 & 0.027 & 0.013 & 0.026 & 0.038 & 0.083 \\
\hline 773 & 953 & 73 & 0 & 0.009 & 0.958 & 2,349 & 0.008 & 0.03 & 0.013 & 0.022 & 0.041 & 0.091 \\
\hline 775 & 1108 & 85 & 0 & 0.003 & 0.671 & 0.092 & 0.009 & 0.033 & 0.013 & 0.024 & 0.039 & 0.087 \\
\hline 776 & 1180 & 95 & 0 & 0.003 & 0.003 & 0.657 & 0.009 & 0.028 & 0.013 & 0.023 & 0.037 & 0.059 \\
\hline 777 & 994 & 75 & 0 & 0.004 & 1,124 & 0.636 & 0.008 & 0.028 & 0.013 & 0.024 & 0.034 & 0.107 \\
\hline 778 & 1214 & 75 & 0 & 0.003 & 0.019 & 0.094 & 0.009 & 0.029 & 0.014 & 0.023 & 0.041 & 0.075 \\
\hline 779 & 1416 & 75 & 0 & 0.007 & 1,217 & 3,491 & 0.01 & 0.029 & 0.013 & 0.023 & 0.03 & 0.057 \\
\hline 780 & 1246 & 60 & 0 & 0.003 & 0.59 & 0.718 & 0.01 & 0.03 & 0.014 & 0.023 & 0.032 & 0.051 \\
\hline 803 & 1292 & 100 & 0 & 0.003 & 0.007 & 0.02 & 0.009 & 0.03 & 0.013 & 0.025 & 0.044 & 0.066 \\
\hline
\end{tabular}

Table 2. Median concentration of heavy metals $(\mu \mathrm{g} / \mathrm{g})$ in the blood of Anodorhynchus hyacinthinus nestlings and the minimum and maximum values of concentration $(\mu \mathrm{g} / \mathrm{g})$ (Interval)

\begin{tabular}{ccc}
\hline Metals & Median & Min - Max \\
\hline $\mathrm{Cr}$ & 0.10 & $0.05-1.93$ \\
$\mathrm{Fe}$ & $3.06^{\mathrm{a}}$ & $0.00-30.43$ \\
$\mathrm{Al}$ & $3.46^{\mathrm{a}}$ & $0.00-87.28$ \\
$\mathrm{As}$ & $<\mathrm{LoQ}$ & \\
$\mathrm{Cd}$ & $0.25^{\mathrm{b}, \mathrm{c}}$ & $0.15-0.50$ \\
$\mathrm{Cu}$ & $0.74^{\mathrm{a}, \mathrm{c}, \mathrm{d}}$ & $0.52-1.28$ \\
$\mathrm{~Pb}$ & $<\mathrm{LoQ}$ & \\
$\mathrm{Mo}$ & $0.33^{\mathrm{b}, \mathrm{c}}$ & $0.22-0.77$ \\
$\mathrm{Ni}$ & $0.61^{\mathrm{a}, \mathrm{c}}$ & $0.40-1.00$ \\
$\mathrm{Se}$ & $0.98^{\mathrm{a}, \mathrm{d}, \mathrm{f}}$ & $0.65-1.63$ \\
$\mathrm{Zn}$ & $2.08^{\mathrm{a}, \mathrm{d}, \mathrm{e}, \mathrm{fg}}$ & $1.23-11.17$
\end{tabular}

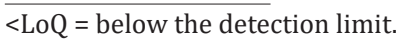

Table 3. Classification of nests and hatching success of Anodorhynchus hyacinthinus eggs according to the quantification of the metals

\begin{tabular}{lccc}
\hline Classification & $\begin{array}{c}\text { Nests with all } \\
\text { hatched eggs }\end{array}$ & $\begin{array}{c}\text { Nests with } \\
\text { unhatched eggs }\end{array}$ & Total \\
\hline $\begin{array}{l}\text { Reference } \\
\text { Answer }\end{array}$ & 22 & 0 & 22 \\
Total & 0 & 4 & 4 \\
\multicolumn{2}{c}{ DISCUSSION } & 4 & 26 \\
& 22 &
\end{tabular}

The Ni levels found in this study were similar to the ones found by Abduljaleel et al. (2012) in blood analysis of quails (Coturnix coturnix japonica). On the other hand, the values of $\mathrm{Cr}, \mathrm{Fe}, \mathrm{Al}, \mathrm{Cu}$, Se and $\mathrm{Zn}$ were much lower in the.
Table 4. Influence of heavy metal concentration in the hatching success of Anodorhynchus hyacinthinus eggs

\begin{tabular}{lcccc}
\hline Variable & Coefficient & Standard deviation & Statistical test & $\mathrm{P}$ \\
\hline Constant & 332.515 & 81650.138 & 0.0000166 & 0.997 \\
$\mathrm{Cr}$ & 67777.603 & 5164500.722 & 0.000172 & 0.990 \\
$\mathrm{Fe}$ & -0.0298 & 9.909 & 0.00000902 & 0.998 \\
$\mathrm{Al}$ & -0.132 & 11.918 & 0.000123 & 0.991 \\
$\mathrm{Cd}$ & 1923.364 & 2828317.717 & 0.000000462 & 0.999 \\
$\mathrm{Cu}$ & -810.684 & 426446.369 & 0.00000361 & 0.998 \\
$\mathrm{Mo}$ & 26613.014 & 2122214.856 & 0.000157 & 0.990 \\
$\mathrm{Ni}$ & -23275.505 & 2763082.282 & 0.0000710 & 0.993 \\
$\mathrm{Se}$ & -13303.577 & 909040.841 & 0.000214 & 0.988 \\
$\mathrm{Zn}$ & 783.267 & 96042.564 & 0.0000665 & 0.993
\end{tabular}

The values of $\mathrm{Cd}$ found in were higher than those found by Fritsch et al. (2012) in blackbirds (Turdus merula) and higher than those found by Abduljaleel et al. (2012) in quails (Coturnix coturnix japonica).

The $\mathrm{Cd}$ is a toxic heavy metal that even at very low concentrations leads to changes in metabolism and affects development (Burger \& Gochfeld 1994, 1997, Spahn \& Sherry 1999). However, the growth of nestlings was not affected by levels of contamination, because weight had no significant relationship with the levels of metals in the blood. This confirmed the findings of Janssens et al. (2003) in Belgiun, where independent of the gradient of pollution the weight of great tit nestlings (Parus major) showed no significant differences. The same results were obtained in studies of Southern House Wren (Troglodytes musculus) (Hofer et al. 2010) and Pied Flycatcher (Ficedula hypoleuca) (Eeva \& Lehikoinen 1996). 
This study found no significant relationship between age and concentration of heavy metals in nestlings, corroborating the findings of Hofer et al. (2010), in the USA with Southern House Wren nestlings (Troglodytes musculus). The relationship between these findings may be explained by the importance of age in bioaccumulation (Furness 1993), and by blood samples indicating recent exposure levels (Garcia-Fernandez et al. 1996).

Previous studies have found changes in bird's population stability due to heavy metal contamination, which reflected directly in the reproduction of these animals, reducing hatching success (Eeva et al. 1997, Eeva et al. 2009).

The hatching success of eggs did not change when in relation to the concentration of heavy metals, which suggests that the contamination of the studied place is still not high enough to influence the reproduction of the species. Supporting this idea, Eeva et al. (2009) studied the effects of three different levels of pollution in hatching success of great tit (Parus major), in Finland, and found lower rates of hatching in the more polluted areas.

There are several studies on the influence of heavy metal contamination in the organism of birds in many countries; however, among the species of birds found in Brazil, this is the first study with a parrot, the A. hyacinthinus.

The nestlings used in this study, in general, showed no changes in their organism resulting from environmental contamination, suggesting that this type of contamination is not yet at alarming levels for nestlings. Therefore, the hypothesis that the presence of heavy metals in the organism of Anodorhynchus hyacinthinus nestlings could influence the weight and age of the same and the hatching success of eggs was not confirmed. It is important to high light that this study was carried out with the nestlings blood samples, which shows recent contamination and short exposure time, and therefore does not exhibit the actual condition in relation to physiological and reproductive damage in the population.

\section{CONCLUSIONS}

There are $\mathrm{Cr}$ levels of $(0.10 \mathrm{mg} / \mathrm{g}) \mathrm{Fe}(3.06 \mathrm{mg} / \mathrm{g}) \mathrm{Al}$ (3.46mg/g), Cd (0.25mg/g), Cu (0.74mg/g), Mo (0.33mg/g), $\mathrm{Ni}(0.61 \mathrm{mg} / \mathrm{g})$, Se $(0.98 \mathrm{mg} / \mathrm{g})$ and $\mathrm{Zn}(2.08 \mathrm{mg} / \mathrm{g})$ found in the organism of Anodorhynchus hyacinthinus nestlings.

The presence of these metals, the concentrations obtained in this study, does not influence the growth of nestlings and the hatching success of eggs.

The blood exam is a potential minimally invasive method for the determination of recent contamination in birds.

\section{REFERENCES}

Abduljaleel S.A., Shuhaimi-Othman M. \& Babji A. 2012. Assessment of trace metals contents in chicken (Gallus gallus domesticus) and quail (Coturnix coturnix japonica) tissues from Selangor (Malaysia). J. Environ. Sci. Technol. 5:441-451.

Bost C.A. \& Lemaho Y. 1993. Seabirds as bioindicators of changing marine ecosystems: new perspectives. Acta Oecologica 14:463-470.
Burger J. 1993. Metals in avian feathers: bioindicators of environmental pollution. Rev. Environ. Toxicol. 5:203-311.

Burger J. \& Gochfeld M. 1994. Behavioral impairments of lead injected young herring gulls in nature. Fundamental and Applied Toxicology 23:353-361

Burger J. \& Gochfeld M. 1997. Lead and neurobehavioral development in gulls: a model for understanding effects in the laboratory and the field. Neurotoxicology 18:486-506.

Cubas Z.S. \& Godoy S.N. 2012. Algumas Doenças de Aves Ornamentais. Disponível em <http://www.canarilalmada.com/download/download/ Dossierdedoencas.pdf> Acesso em 10 jan. 2013.

Dmowski K. 1999. Birds as bioindicators of heavy metal pollution: review and examples concerning European species. Acta Ornithologica 34:1-25.

Eeva T. \& Lehikoinen E. 1996. Growth and mortality of nestling great tits (Parus major) and pied flycatchers (Ficedula hypoleuca) in a heavy metal pollution gradient. Oecologia 108:631-639.

Eeva T., Lehikoinen E. \& Pohjalainen T. 1997. Pollution-related variation in food supply and breeding success in two hole-nesting passerines. Ecology 78:1120-1131.

Eeva T., Ahola M. \& Lehikoinen E. 2009. Breeding performance of blue tits (Cyanistes caeruleus) and great tits (Parus major) in a heavy metal polluted area. Environmental Pollution 157:3126-3131.

Fritsch C., Coeurdassier M., Faivre B., Baurand P.E., Giraudoux P., Nico W.B. \& Scheifler R. 2012. Influence of landscape composition and diversity on contaminant flux in terrestrial food webs: a case study of trace metal transfer to European blackbirds Turdus merula. Science of the Total Environment 432:275-287.

Furness R.W. 1993. Birds as monitors of pollutants, p.86-143. In: Furness R.W. \& Greenwood J.J.D. (Eds), Birds as Monitors of Environmental Change. Chapman and Hall, London.

Garcla-Fernandez A.J. 1994. Impregnacion por plomo y cadmio en aves silvestres de la Region de Murcia. Tese de Doutorado. Servicio de Publicaciones, Universidad de Murcia.

Garcı-Fernandez A.J., Sanchez-Garcıa J.A., Go Mez-Zapata M. \& Luna A. 1996. Distribution of cadmium in blood and tissues of wild birds. Archs Environ. Contamin. Toxicol. 30:252-258.

Guedes N.M.R. 2009. Sucesso reprodutivo, mortalidade e crescimento de filhotes de araras-azuis Anodorhynchus hyacinthinus (Aves, Psittacidae) no Pantanal, Brasil. Tese de Doutorado, Universidade Estadual Paulista (Unesp), Botucatu, SP.

Hofer C., Gallagher F.J. \& Holzapfel C. 2010. Metal accumulation and performance of nestlings of passerine bird species at an urban brownfield site. Environmental Pollution 158:1207-1213.

Janssens E., Dauwe T., Bervoets L. \& Eens M. 2002. Inter- and intraclutch variability in heavy metals in feathers of great tit nestlings (Parus major) along a pollution gradient. Archs Environ. Contamin. Toxicol. 43:323-329.

Janssens E., Dauwe T., Pinxten R. \& Eens M. 2003. Breeding performance of great tits (Parus major) along a gradient of heavy metal pollution. Environ. Toxicol. Chem. 22:1140-1145.

Jaspers V., Dauwe T., Pinxten R., Bervoets L., Blust R. \& Eens M. 2004. The impact of exogenous contamination on heavy metal levels in birds. A field experiment with free-living great tits, Parus major. Environmental Monitoring 6:356-360.

Nunes A.P., Tomas W.M. \& Ticianeli F.A.T. 2005. Aves da Fazenda Nhumirim, Pantanal da Nhecolândia. Corumbá, MS.

Pereira G.C. \& Ebecken N.F.F. 2009. Knowledge discovering for coastal waters classification. Expert Systems with Applications 36:8604-8609.

Spahn S.A. \& Sherry T.W. 1999. Cadmium and lead exposure associated with reduced growth rates, poorer fledgling success of little blue herons chicks (Egretta caerulea) in South Louisiana wetlands. Archs Environ. Contamin. Toxicol. 37:377-384. 